\title{
ANALISIS STRATEGI PENGEMBANGAN USAHA TAHU TEGUH PRIBADI DI BENGKULU TENGAH
}

\author{
Eska Prima Monique 1), Suswati Nasution 2) \\ 1)Program Studi Manajemen Fakultas Ekonomi Universitas Dehasen Bengkulu \\ 2) Program Studi Keuangan \& Perbankan Fakultas Ekonomi Universitas Dehasen Bengkulu \\ monique.ds@unived.ac.id ; suswatinasution@unived.ac.id
}

\begin{abstract}
ABSTRAK
Eska Prima Monique, Suswati Nasution ; Usaha kecil dan menengah (UKM) yang sekarang lebih dikenal dengan usaha mikro kecil dan menengah (UMKM) memegang peranan penting dalam pertumbuhan perekonomian Indonesia. Perusahaan melakukan analisis SWOT (Strength, Weakness, Oppurtunity, and Threat) dalam menentukan strategi pemasaran.Responden dalam penelitian ini adalah produsen tahu, pemasok, konsumen, pemerintah, pesaing dan lembaga pemasaran Tahu Teguh Pribadi. Dimana analisis ini terdiri dari 2 variabel analisis, yaitu analisis faktor internal yang terdiri dari kekuatan dan kelemahan, dan analisis eksternal yang terdiri dari peluang dan ancaman. Matriks IFAS (Internal Factor Analysis Summary) menunjukan bahwa faktor kekuatan dan kelemahan memiliki total skor 3,01. Matrik EFAS (External Factor Analysis Strategi ) menunjukkan bahwa faktor peluang dan ancaman memiliki nilai total 3,16. Berdasarkan diagram Cartesius menunjukan bahwa Usaha Tahu Teguh Pribadi berada pada kuadran Growth dimana kuadran tersebut merupakan situasi yang sangat menguntungkan. Strategi SO (StrenghtOpportunity) maka diperoleh lah faktor yang harus dipertahankan untuk mampu mengambil peluang yang ada yaitu : Peningkatan kualitas produk dengan pemanfaatan perkembangan teknologi untuk menjaga kepercayaan konsumen daan membentuk asosiasi/serikat pengusaha tahu guna menjaga bargaining position terhadap pemasok. Strategi W-O (Weakness-Opportunity) diperoleh hasil yaitu: Meningkatkan volume penjualan melalui diversifikasi produk dengan memanfaatkan kebijakan mengenai kuliner dan Peningkatan kualitas SDM melalui program-program dari pemerintah.Strategi S-T (Strenght Threat) menampakkan hasil yaitu: Meningkatkan kualitas dan menjaga kontinuitas produk dengan manajemen produksi yang baik untuk meningkatkan daya saing. Serta dapat meningkatkan efisiensi pemasaran dengan menjalin hubungan kemitraan Strategi W-T (Weakness- Threat) yaitu": Penggunaan SOP secara sederhana guna keefektifan dan efissien. Serta Peningkatan jejaring permodalan dan promosi melalui kemasan produk serta peningkatan SDM
\end{abstract}

\begin{abstract}
Eska Prima Monique, Suswati Nasution;. Small and medium enterprises (SMEs) which are now better known as micro and small enterprises play an important role in the growth of the Indonesian economy. The company carries out a SWOT analysis (Strength, Weakness, Oppurtunity, and Threat) in determining marketing strategies. The respondents in this study are tofu producers, suppliers, consumers, governments, competitors and marketing institutions of Tahu Teguh Pribadi. Where this analysis consists of 2 analysis variables, namely an analysis of internal factors consisting of strengths and weaknesses, and external analysis consisting of opportunities and threats. The IFAS (Internal Factor Analysis Summary) matrix shows that the strength and weakness factors have a total score of 3.01. The EFAS (External Factor Analysis Strategy) matrix shows that opportunity and threat factors have a total value of 3.16. Based on the Cartesian diagram shows that Usaha Tahu Teguh Pribadi is in the Growth quadrant where the quadrant is a very favorable situation. S-O strategy (Strenght-Opportunity) then obtained the factor that must be maintained to be able to take the opportunities that are: Improving product quality by utilizing technological developments to maintain consumer trust and forming associations / unions of business entrepreneurs to maintain bargaining positions against suppliers. The W-O strategy (Weakness-Opportunity) obtained results, namely: Increasing sales volume through product diversification by utilizing culinary policies and improving the quality of human resources through programs from the government. S-T strategy (Great Strenght) shows results: Improving quality and maintaining product continuity with good production management to improve competitiveness. And can improve marketing efficiency by establishing W-T (Weakness-Threat) Strategy partnership relationship, namely: Use simple SOPsfor effectiveness and efficiency. As well as increasing capital and promotion networks through product packaging and increasing human resources
\end{abstract}

Key Words: SWOT Analysis, Business Development Strategy, IFAS and EFAS 


\section{LATAR BELAKANG}

Salah satu penilaian terhadap suatu negara adalah pada sektor ekonomi.Perekonomian suatu negara diharapkan selalu mengalami pertumbuhan sehingga terjadi peningkatan kelayakan hidup masyarakat.Pertumbuhan ekonomi menunjukan sejauh mana aktivitas perekonomian akan menghasilkan tambahan pendapatan masyarakat pada suatu periode tertentu. Usaha kecil dan menengah (UKM) yang sekarang lebih dikenal dengan usaha mikro kecil dan menengah (UMKM) memegang peranan penting dalam pertumbuhan perekonomian Indonesia. Selain memberikan lapangan pekerjaan baru, UKM mampu mendorong pertumbuhan ekonomi pasca krisis moneter tahun 1997 di mana perusahaan-perusahaan besar mengalami kesulitan dalam mengembangkan usahanya (Wurdayanti, 2013)

Usaha tahu merupakan usaha keluarga yang bergerak di usaha perdagangan, selain itu usaha tahu ini juga memberikan lapangan pekerjaan bagi masyrakat setempat. usaha tahu Teguh Pribadi merupakan salah satu UMKM yang ada di Kabupaten Bengkulu Tengah yang bergerak di bidang pembuatan tahu.

Perhatian pemerintah terhadap UMKM mulai meningkat sejak keluarnya Intruksi Presiden No. 6 tahun 2007 tentang kebijakan percepatan pengembangan sekrtor Rill dan pemberdayaan usaha mikro kecil dan menengah. Intruksi presiden tersebut memberikan tugas kepada seluruh menteri, kepala lembaga pemerintah non departermen ,Gubernur dan bupati/wali koita untuk mengambil langkahlangkah yang diperlukan guna mempertahan dan meningkatkan UMKM di wilayahnya.

Di Kabupaten Bengkulu Tengah banyak Pengusaha kecil dan menengah yang bergerak pada usaha industri keluarga atau rumahan. Usaha tahu Teguh Pribadi merupakan salah satu UMKM yang ada di Kabupaten Bengkulu Tengah, usaha ini bergerak pada bidang pembuatan tahu.

Berdasarkan uraian diatas dan mengingat pentingnya studi kelayakan Perluasan usaha tahu di kota Bengkulu, maka dipandang perlu untuk mengadakan penelitian pada usaha tahu Teguh Pribadi kota Bengkulu. Dalam kasus ini, penulis tertarik untuk mengadakan penelitian guna menelusuri permasalahan dan sekaligus menganalisa "analisis strategi pengembangan usaha pada Tahu Teguh Pribadi di Bengkulu Tengah"

\section{LANDASAN TEORI Manajamen Strategi}

Manajemen adalah serangkaian penuh komitmen, keputusan, dan tindakan yang diperlukan oleh sebuah perusahaan untuk mencapai daya saing strategis dan menghasilkan diatas rata-rata. Input strategi relevan berasal dari analisis lingkungan eksternal dan internal, diperlukan untuk formulasi dan implementasi strategi yang efektif. Sebaliknya, tindakan strategis efektif adalah persyarat untuk dapat mencapai hasil yang diinginkan bagi daya saing strategis dan laba diatas rata-rata. Jadi, manajemen strategis digunakan untuk mencocokan kondisi pasar dan struktur persaingan yang selalu berubah dengan sumber daya, kapabilitas, dan kompetensi (sumber input srategis) perusahaan yang terus menerus berkembang. Tindakan srategis efektif yang dilakukan dalam konteks formulasi dan implementasi strategis yang diintegrasikan dengan cermas akan menghasilkan output strategis (outcome strategic) yang diinginkan (Michael, 2001)

Pada dasarnya setiap perusahaan mempunyai strategi dalam berusaha. Namun, mungkin saja terjadi seorang pemimpin perusahaan tidak menyadarinya. Dalam mengkaji strategi perusahaan, perlu diketahui bahwa bentuk strategi akan berbeda-beda antara industry, antar perusahaan, dan bahkan antar situas. Namun, ada sejumlah strategi yang sudah banyak diketahui umum dan dapat diterapkan pada berbagai bentuk industri dan ukuran perusahaan. Menurut Solihin (2012) disajikan paparan 3 macam model Strategi Generik. Untuk menjelaskan tentang strategi, Whelen dan Hunger menggunakan konsep dari General Electric. General Electric menyatakan bahwa pada prinsipnya strategi generik dibagi atas tiga macam yaitu, strategi Stabilitas (stability), ekspansi (expansion), dan penciutan (rentrencment) berikut dapat dilihat penjelasnya :

1) Strategi Stabilitas (Stability)

Pada prinsipnya, strategi ini menekankan pada tidak bertambahnya produk, pasar dan fungsi-fungsi perusahaan lain, karena perusahaan berusaha untuk meningkatkan efesiensi disegala bidang dalam rangka meningkatkan kinerja dan keuntungan. Strategi ini resikonya relative rendah dan biasanya dilakukan untuk produk yang tengah berada pada posisi kedewasaan (mature).

2) Strategi Ekspansi (Expansion)

Pada prinsipnya, strategi ini menekankan pada penambahan atau perusahaan produk, pasar dan fungsi-fungsi perusahaan lainnya,sehingga aktivitas perusahaan meningkat. Tetapi, selain keuntungan yang ingin diraih lebih besar, strategi ini juga mengandung resiko kegagalan yang tidak kecil. 
3) Strategi Penciutan (Rentrencment)

Pada prinsipnya, strategi ini dimaksudkan untuk melakukan pengurangan atas produk yang dihasilkan atau pengurangan atas pasar maupun fungsi-fungsi dalam perusahaan, khususnya yang mempunyai cashflow negatif. Strategi yang biasanya diterapkan pada bisnis yang berada pada tahap menurun (decline). Penciutan ini dapat terjadi karena sumberdaya yang perlu diciutkan itu lebih baik dikerahkan, misalnya untuk usaha lain yang sedang berkembang.

\section{Bauran Pemasaran (Marketing Mix)}

Menurut Kotler (2007) bahwa Bauran Pemasaran (Marketing Mix) adalah seperangkat alat pemasaran yang digunakan perusahaan untuk terus-menerus mencapai tujuan pemasarannya di pasar sasaran. Berdasarkan definisi tersebut diatas bahwa bauran pemasaran adalah kombinasi beberapa elemen bauran pemasaran untuk memperoleh pasar, pangsa pasar yang lebih besar, posisi bersaing yang kuat dan citra positif pada pelanggan sehingga dapat kita artikan bahwa tujuan pemasaran adalah untuk meningkatkan jumlah pelanggan, meningkatkan hasil penjualan, serta dapat memberikan keuntungan untuk perusahaan dan stakeholdernya. Strategi marketing mix terdiri dari 4P yaitu product (produk), price (harga), place (tempat), dan product (promosi)

\section{Mengembangkan Strategi Produk}

Pengembangan produk (product develoment) adalah sebuah strategi yang mengupayakan peningkatan penjualan dengan cara memperbaiki atau memodifikasi produk atau jasa yang ada saat ini. Pengembangan produk biasanya membutuhkan pengeluaran yang sangat besar untuk penelitian dan pengembangan.

Menurut Triyana dalam Malinda (2017) terdapat lima pedoman dalam pengembangan produk dapat menjadi strategi yang sangat efektif:

1) Ketika organisasi memiliki produk-produk berhasil yang berada ditahap kematangan dari siklus hidup produk, gagasan disini adalah menarik konsumen yang terpuaskan untuk mencoba produk baru yang lebih baik sebagai hasil dari pengalaman positif mereka dengan produk atau jasa organisasi saat ini

2) Ketika organisasi berkompetisi di industri yang ditandai oleh perkembangan tekonologi yang cepat.

3) Ketika pesaing utama menawarkan produk berkualitas lebih baik dengan harga bagus.

4) Ketika organisasi bersaing dalam industri dalam tingkat pertumbuhan yang tinggi.

5) Ketika organisasi memiliki kapasitas penelitian dan pengembangan yang sangat kuat.

\section{Strategi Pemasaran}

Menurut Tjiptono (2002) Strategi berasal dari kata yunani Strategeia (sratus = militer, ag = memimpin) yang artinya seni atau ilmu untuk menjadi seorang jendral. Konsep strategi seringkali diadaptasi dan diterapkan didunia bisnis. Strategi dapat didefenisikan sebagai program untuk menentukan dan mencapai tujuan dan organisasi dan mengimplementasi misinya

Oleh karena itu menurut Cannon (2009) pemasaran memainkan peranan penting dalam pengembangan strategi. Dalam peranan strategisnya, pemasaran mencakup setiap usaha untuk mencapai kesesuaian antara perusahaan dengan lingkungannya dalam rangka mencari pemecahan atas masalah penentuan dua pertimbangan pokok.

Pertama, bisnis apa yang digeluti perusahaan pada saat ini dan jenis bisnis apa yang dapat dimasuki dimasa mendatang. Kedua, bagaimana bisnis yang telah dipilih tersebut dapat dijalankan dengan sukses dalam lingkungan yang kompetitif atas dasar perspektif produk, harga, promosi, dan distribusi (bauran pemasaran) untuk melayani pasar sasaran

\section{Analisis SWOT}

Analisis SWOT adalah sebuah metode perencanaan strategis untuk mengevaluasi suatu bisnis usaha. Analisis ini melibatkan penentuan tujuan usaha dan mengidentifikasi faktor-faktor internal dan eksternal yang baik untuk mencapai tujuan usaha. Pearce dan Robinson (2008) menyatakan "analisis SWOT merupakan teknik historis yang terkenal dimana para manajer menciptakan gambaran umum secara mengenai situasi strategi perusahaan". Rangkuti (2009) menjelaskan bahwa sel 1 merupakan situasi yang paling diinginkan oleh satuan bisnis, karena dalam sel ini satuan bisnis menghadapi berbagai peluang lingkungan dan memiliki berbagai peluang tersebut. Berikut merupakan diagram SWOT yang digunakan untuk melihat posisi perusahaan yang dapat dilihat pada gambar 1. 


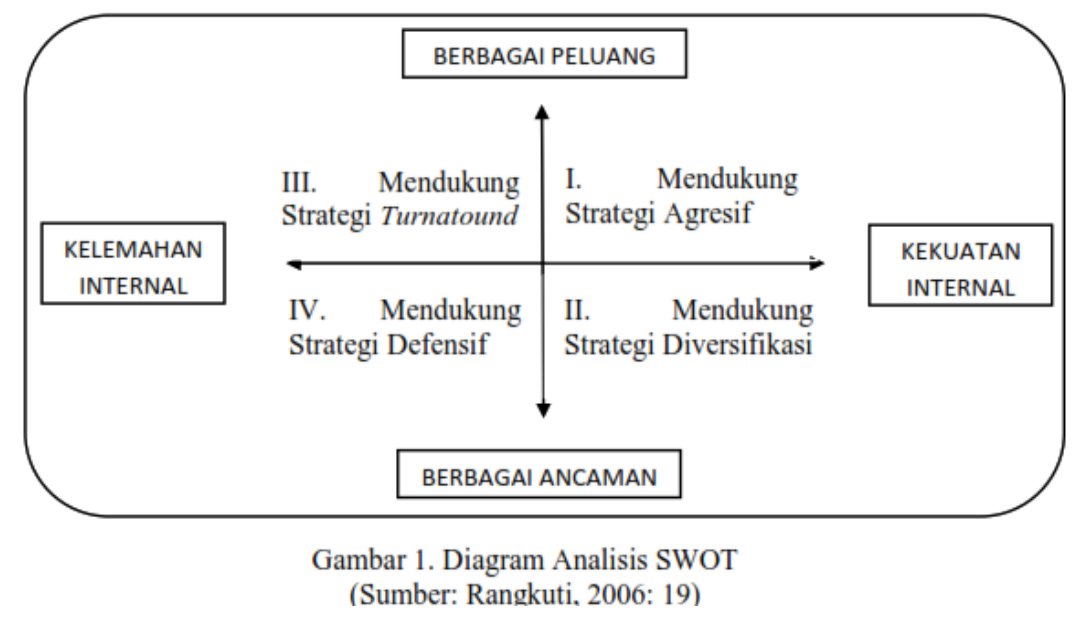

a. Kuadran I

(Sumber: Rangkuti, 2006: 19)

Merupakan situasi yang sangat menguntungkan perusahaan tersebut memiliki peluang dan kekuatan sehingga dapat memanfaatkan peluang yang ada. Strategi yang harus diterapkan dalam kondisi ini adalah mendukung kebijakan pertumbuhan yang agresif (growth oriented strategy).

b. Kuadran II

Meskipun menghadapi berbagai ancaman, perusahaan ini masih memiliki kekuatan dari segi internal. Strategi yang harus diterapkan adalah menggunakan kekuatan untuk memanfaatkan peluang jangka panjang dengan cara strategi diversifikasi (produk jasa)

c. Kuadran III

Perusahaan memiliki peluang pasar yang sangat besar, dilain pihak memiliki berbagai kendala/ kelemahan internal. Fokus perusahaan ini adalah meminimalkan masalah-masalah internal perusahaan sehingga dapat merebut peluang pasar yang lebih baik.

d. Kuadran IV

Merupakan situasi yang tidak menguntungkan. Perusahaan tersebut menghadapi berbagai ancaman dan kelemahan internal. Strategi yang digunakan adalah strategi defensif.

\section{Matriks SWOT}

Matriks SWOT adalah alat yang dipakai untuk menyusun faktor-faktor strategi perusahaan. Matriks ini dapat menggambarkan secara jelas bagaimana peluang dan ancaman eksternal yang dihadapi perusahaan disesuaikan dengan kekuatan dan kelemahan yang dimiliki (Rangkuti, 2009). Matriks ini dapat menghasilkan empat set alternatif strategi

Tabel 1 Matrik SWOT

\begin{tabular}{|l|l|l|}
\hline $\begin{array}{l}\text { Faktor- } \\
\text { faktor } \\
\text { Internal } \\
\text { faktor } \\
\text { Eksternal }\end{array}$ & $\begin{array}{l}\text { Kekuatan (S) 5-10 } \\
\text { Daftarkan } \\
\text { faktor-faktor internal }\end{array}$ & $\begin{array}{l}\text { Kelemahan (W) } \\
\text { Daftarkan 5-10 faktor- } \\
\text { faktor internal }\end{array}$ \\
\hline $\begin{array}{l}\text { Peluang (O) } \\
\text { Daftarkan 5-10 faktor- } \\
\text { faktor peluang eksternal }\end{array}$ & $\begin{array}{l}\text { Strategi (SO) } \\
\text { Buat strategi disini } \\
\text { yang menggunakan } \\
\text { kekuatan untuk } \\
\text { memanfaatkan } \\
\text { peluang }\end{array}$ & $\begin{array}{l}\text { Strategi (WO) } \\
\text { Buat strategi disini } \\
\text { yang memanfaatkan } \\
\text { peluang mengatasi } \\
\text { ancaman }\end{array}$ \\
\hline $\begin{array}{l}\text { Ancaman (T) } \\
\text { Daftarkan 5-10 faktor- } \\
\text { faktor ancaman eksternal }\end{array}$ & $\begin{array}{l}\text { Strategi (ST) } \\
\text { Buat strategi disini } \\
\text { yang menggunakan } \\
\text { kekuatan untuk } \\
\text { mengatasi ancaman }\end{array}$ & $\begin{array}{l}\text { Strategi (WT) } \\
\text { Buat strategi disini } \\
\text { yang meminimalkan } \\
\text { kelemahan dan } \\
\text { menghindari ancaman }\end{array}$ \\
\hline
\end{tabular}

Sumber : Rangkuti (2009) 


\section{Matriks IFAS dan EFAS}

Pada fase ini, kita telah membahas bagaimana perusahaan menilai situasinya dan juga telah meninjau strategi perusahaan yang tersedia. Tugas selanjutnya adalah melakukan identifikasi atau alternatif yang dapat menggunakan kesempatan dan peluang atau menghindari ancaman dan mengatasi kelemahan. Rangkuti (2009), SWOT adalah identitas berbagai faktor secara sistematis untuk merumuskan strategi pelayanan. Analisis ini dapat memaksimalkan peluang dan secara bersamaan dapat meminimalkan kekurangan dan ancaman. Analisis SWOT membandingkan antara faktor eksternal dan faktor internal.

a. Matriks Internal Factors Analysis Summary (IFAS)

Matriks IFAS digunakan untuk mengetahui seberapa besar peranan dari faktor-faktor internal yang terdapat pada perusahaan. Matriks IFAS menggambarkan kondisi internal perusahaan yang terdiri dari kekuatan dan kelemahan yang dihitung berdasarkan rating dan bobot. Berikut ini adalah bentuk matriks IFAS

b. Matriks Eksternal Factors Analysis Summary (EFAS)

Matriks EFAS digunakan untuk mengetahui seberapa besar peranan dari faktor-faktor internal yang terdapat pada perusahaan. Matriks EFAS menggambarkan kondisi eksternal perusahaan yang terdiri dari peluang dan ancaman yang dihitung berdasarkan bobot dan rating.

\section{KERANGKA ANALISIS}

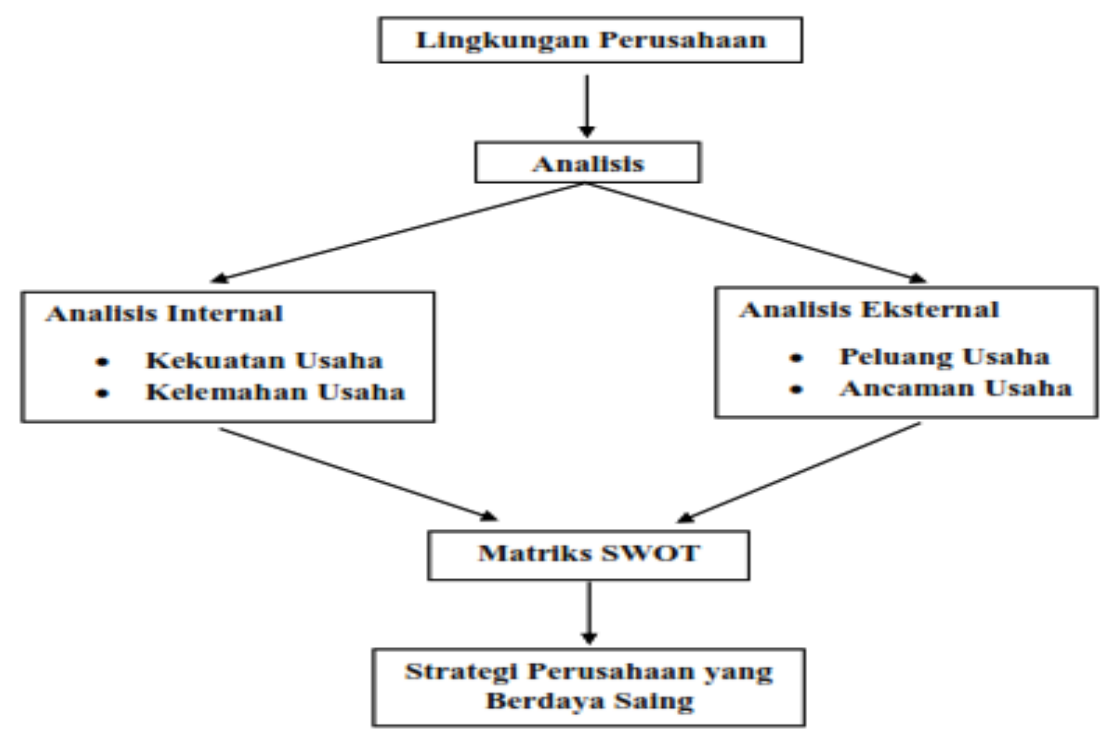

Sumber : Rangkuti (2009)

\section{METODOLOGI}

Gambar 2. Kerangka Analisis

Penelitian ini termasuk ke dalam penelitian deskriptif kualitatif, Karena bertujuan untuk menggambarkan keadaan atas fenomena dilapangan. Arikunto (2007) menyatakan penelitian deskriptif adalah suatu penelitian yang bertujuan untuk menggambarkan atau memaparkan sesuatu hal, misalnya keadaan, kondisi, situasi, peristiwa, kegiatan dan lain-lain. Sugiyono (2012) metode penelitian kualitatif adalah metode penelitian yang berlandaskan pada filsafat post positivisme, yang digunakan untuk meneliti suatu objek yang alamiah yang menjadikan peneliti sebagai instrumen kunci. Pada teknik penelitian ini peneliti menggunakan pengumpulan data melalui tiga cara yaitu dengan pengamatan (observasi), wawancara (interview), dan dokumentasi.

Penelitian ini berusaha menggambarkan atau mengetahui tingkat kelebihan, kekurangan, peluang dan ancaman usaha Tahu Teguh Pribadi. Penelitian ini memberikan suatu rumusan perencanaan strategi pemasaran baru untuk Tahu Teguh Pribadi yang nantinya dapat diterapkan oleh pengelola usaha. Usaha tahu di Bengkulu Tengah menepati lokasi yang cukup luas terletak dilokasi yang strategis, tetapi susah untuk dijangkau karena berada di kabupaten Bengkulu Tengah, dikawasan pabrik dan tidak ramai penduduk alamat usaha tahu teguh pribadi adalah di Desa Pulo Bringin kabupaten bengkulu tengah. Responden dalam penelitian ini adalah produsen tahu, pemasok, konsumen, pemerintah, pesaing dan 
lembaga pemasaran Tahu Teguh Pribadi. Metode pengumpulan data yang digunakan dalam penelitian ini meliputi:

a. Metode wawancara

Esterberg (2002) mendefinisikan wawancara adalah pertemuan dua orang untuk bertukar informasi dan ide melalui tanya jawab, sehingga dapat dikontruksikan makna dalam suatu topik tertentu. Wawancara yang digunakan oleh peneliti merupakan wawancara semi terstruktur. Jenis wawancara ini dalam pelaksanaannya lebih bebas bila dibandingkan wawancara terstruktur. Tujuan dari wawancara adalah untuk menemukan permasalahan secara lebih terbuka, dimana pihak yang diajak wawancara diminta pendapat dan ide-idenya (Sugiyono, 2012).

b. Metode Observasi

Observasi merupakan teknik pengumpulan data yang mempunyai ciri yang spesifik bila dibandingkan dengan teknik yang lain yaitu wawancara dan kuesioner. Observasi tidak selalu dengan objek manusia tetapi juga objek-objek alam yang lain. Sugiyono (2012) mengemukakan bahwa observasi merupakan suatu proses yang kompleks, suatu proses yang tersusun dari berbagai proses biologis dan psikologis. Dua diantara yang terpenting adalah proses-proses pengamatan dan ingatan. Penelitian lapangan ini dilakukan untuk memperoleh data yang diperlukan dalam penelitian. Adapun langkahlangkah yang digunakan adalah dengan melakukan pengamatan langsung terhadap usaha tahu Tahu Teguh Pribadi untuk memperoleh gambaran yang nyata.

c. Metode Dokumentasi

Hamidi (2010) Metode dokumentasi adalah informasi yang berasal dari catatan penting baik dari lembaga atau organisasi maupun dari perorangan. Dokumentasi penelitian ini merupakan pengambilan gambar oleh peneliti untuk memperkuat hasil penelitian. Sugiyono (2012) dokumentasi bisa berbentuk tulisan, gambar atau karya-karya monumentel dari seseorang.

Teknik analisis data yang digunakan dalam penelitian ini adalah mengacu pada konsep Milles et.al (2014) yaitu interactive model yang mengklasifikasikan analisis data dalam tiga langkah, yaitu:

1. Reduksi data (Data Reduction), yaitu suatu proses pemilahan, pemusatan perhatian pada penyederhanaan, pengabstrakan dan transformasi data kasar yang muncul dari catatan-catatan tertulis di lapangan.

2. Penyajian data (Display Data), data ini tersusun sedemikian rupa sehingga memberikan kemungkinan adanya penarikan kesimpulan dan pengambilan tindakan. Adapun bentuk yang lazim digunakan pada data kualitatif terdahulu adalah dalam bentuk teks naratif.

3. Penarikan kesimpulan (Verifikasi), dalam penelitian ini akan diungkap mengenai makna dari data yang dikumpulkan. Dari data tersebut akan diperoleh kesimpulan yang tentatif, kabur, kaku dan meragukan, sehingga kesimpulan tersebut perlu diverifikasi. Verifikasi dilakukan dengan melihat kembali reduksi data maupun display data sehingga kesimpulan yang diambil tidak menyimpang.

\section{HASIL PENELITIAN DAN PEMBAHASAN} Analisis SWOT

\begin{tabular}{|c|c|}
\hline Strength (S) & Weakness (W) \\
\hline $\begin{array}{l}\text { 1. Pengalaman usaha di bidang industri tahu } \\
\text { 2. Hubungan yang baik antar pengusaha } \\
\text { 3. Harga yang terjangkau } \\
\text { 4. Produk yang ditawarkan berkualitas dan unggulan } \\
\text { 5. Saluran distribusi yang pendek } \\
\text { 6. Kontinuitas produksi terjamin }\end{array}$ & $\begin{array}{l}\text { 1. Modal usaha terbatas } \\
\text { 2. Tingkat pendidikan yang masih rendah } \\
\text { 3. Tidak adanya keragaman produk } \\
\text { 4. Promosi terbatas } \\
\text { 5. Belum melaksanakan pengawasan dan evaluasi } \\
\text { secara baik } \\
\text { 6. Limbah belum dikelola secara optimal } \\
\text { 7. Pengelolaan kurang higienis }\end{array}$ \\
\hline Opportunity (0) & Threat (T) \\
\hline $\begin{array}{l}\text { 1. Adanya perhatian dari Pemerintah } \\
\text { 2. Adanya kepercayaan dari konsumen } \\
\text { 3. Kontinuitas bahan baku terjamin } \\
\text { 4. Pedagang membantu memperluas pemasaran } \\
\text { 5. Perkembangan teknologi pengolahan }\end{array}$ & $\begin{array}{l}\text { 1. Implementasi kebijakan/peraturan rendah } \\
\text { 2. Proses yang rumit untuk mendapatkan pinjaman } \\
\text { modal dari Dinas Koperasi } \\
\text { 3. Adanya Persaingan Kualitas dan Kuantitas tahu } \\
\text { antar industri tahu } \\
\text { 4. Adanya fluktuasi harga bahan baku } \\
\text { 5. Harga produk sama dari pesaing yang lebih } \\
\text { murah }\end{array}$ \\
\hline
\end{tabular}

Sumber : Hasil Penelitian dan Observasi, 2019 


\section{Identifikasi faktor internal Usaha Tahu Pribadi}

Berapapun banyaknya faktor yag dimasukkan dalam faktor IFAS, total rata-rata tertimbang berkisar antara yang rendah 1,0 dan tertinggi 4,0 dengan rata-rata 2,5, jika rata-rata dibawah 2,5 menandakan secara internal perusahaan lemah, sedangkan total nilai diatas 2,5 mengingindikasikan posisi internal yang kuat.

Tabel 3. Matriks IFAS (Internal Factor Analysis Summary)

\begin{tabular}{|l|l|c|c|c|}
\hline No & \multicolumn{1}{|c|}{ Internal Factor } & Bobot & Rating & Skor \\
\hline & \multicolumn{3}{|c|}{ Strength (S) } \\
\hline 1. & Pengalaman usaha di bidang industri tahu & 0,20 & 4 & 0,80 \\
\hline 2. & Hubungan yang baik antar pengusaha & 0,04 & 4 & 0,16 \\
\hline 3. & Harga yang terjangkau & 0,08 & 4 & 0,32 \\
\hline 4. & Produk yang ditawarkan berkualitas dan unggulan & 0,20 & 3 & 0,60 \\
\hline 5. & Saluran distribusi yang pendek & 0,04 & 4 & 0,16 \\
\hline 6. & Kontinuitas produksi terjamin & 0,04 & 4 & 0,16 \\
\hline & Sub Total & 0,60 & & 2,20 \\
\hline & \multicolumn{1}{|c|}{ Weakness (W) } & 0,15 & 2 & 0,30 \\
\hline 7 & Modal usaha terbatas & 0,04 & 2 & 0,08 \\
\hline 8 & Tingkat pendidikan yang masih rendah & 0,02 & 2 & 0,04 \\
\hline 9 & Tidak adanya keragaman produk & 0,04 & 3 & 0,12 \\
\hline 10 & Promosi terbatas & 0,03 & 1 & 0,03 \\
\hline 11 & $\begin{array}{l}\text { Belum melaksanakan pengawasan dan evaluasi secara } \\
\text { baik }\end{array}$ & 0,06 & 2 & 0,12 \\
\hline 12 & Limbah belum dikelola secara optimal & 0,06 & 2 & 0,12 \\
\hline 13 & Pengelolaan kurang higienis & 0,40 & & 0,81 \\
\hline & Sub Total & 1 & & 3,01 \\
\hline & Total
\end{tabular}

Dari hasil analisis pada tabel 3 IFAS faktor kekuatan dan kelemahan memiliki total skor 3,01. Karena total skor di atas 2,5 berarti ini mengindentifikasikan posisi internal yang kuat.

\section{Identifikasi faktor Eternal Usaha Tahu Pribadi}

Tabel 4. Matrik External Factor Analysis Strategi (EFAS)

\begin{tabular}{|l|l|c|c|c|}
\hline No & \multicolumn{1}{|c|}{ Internal Factor } & Bobot & Rating & Skor \\
\hline & \multicolumn{1}{|c|}{ Opportunity (0) } \\
\hline 1. & Adanya perhatian dari Pemerintah & 0,15 & 4 & 0,60 \\
\hline 2. & Adanya kepercayaan dari konsumen & 0,15 & 3 & 0,45 \\
\hline 3. & Kontinuitas bahan baku terjamin & 0,15 & 4 & 0,60 \\
\hline 4. & Pedagang membantu memperluas pemasaran & 0,04 & 4 & 0,08 \\
\hline 5. & Perkembangan teknologi pengolahan & 0,02 & 4 & 0,16 \\
\hline & \multicolumn{1}{|c|}{ Threat (T) } \\
\hline & Sub Total & 0,51 & 2,09 \\
\hline 7 & Implementasi kebijakan/peraturan rendah & 0,20 & 4 & 0,80 \\
\hline 8 & $\begin{array}{l}\text { Proses yang rumit untuk mendapatkan } \\
\text { pinjaman modal dari Dinas Koperasi }\end{array}$ & 0,15 & 1 & 0,15 \\
\hline 9 & $\begin{array}{l}\text { Adanya Persaingan Kualitas dan Kuantitas tahu } \\
\text { antar industri tahu }\end{array}$ & 0,04 & 3 & 0,12 \\
\hline 10 & Adanya fluktuasi harga bahan baku & 0,10 & 2 & 0,20 \\
\hline & Sub Total & 0,40 & 1 & 1,27 \\
\hline & Total & 1 & & 3,16 \\
\hline
\end{tabular}

Dari hasil analisis tabel 4 EFAS faktor peluang dan ancaman memiliki total skor 3,16 karena total skor mendekati 4.0 berarti ini mengidentifikasikan bahwa perusahaan merespen peluang yang ada dengan cara luar biasa dan menghidari ancaman-ancaman di pasar industri. 


\section{Diagram Cartesius Analisis SWOT}

Berdasarkan tabel diatas diketahui bahwa diketahui bahwa skor total faktor internal sebesar 1,50 dan berada pada kategori sedang. Sementara skor total faktor eksternal sebesar 1,68 berada pada skala sedang juga. Dengan mempergunakan Tabel 3 dan Tabel 4 maka kedudukan/posisi usaha Tahu Teguh Pribadi apabila dianalisis dengan diagram Cartesius sebagai berikut:

Tabel 5 Perbandingan Skor Faktor Internal dan Eksternal

\begin{tabular}{|c|c|c|c|}
\hline IFASrata-rata & $\mathbf{1 , 5 0}$ & EFAS rata-rata & $\mathbf{1 , 6 8}$ \\
\hline Total Skor Kekuatan (S) & 2,20 & Total Skor peluang (0) & 2,09 \\
\hline Total Skor Kelemahan (W) & 0,81 & Total Skor Ancaman (T) & 1,27 \\
\hline S - W & $\mathbf{1 , 3 9}$ & $\mathbf{0}-\mathbf{T}$ & $\mathbf{( 0 , 8 2 )}$ \\
\hline
\end{tabular}

Sumber : Hasil Penelitian 2019, diolah

Berdasarkan tabel di atas maka nampak bahwa titik koordinat posisi Usaha Tahu Teguh Pribadi pada titik-titik sumbu kekuatan 1,50 dan sumbu peluang 1,68. Untuk lebih jelasnya dapat dilihat dalam diagram cartesius sebagaimana berikut :

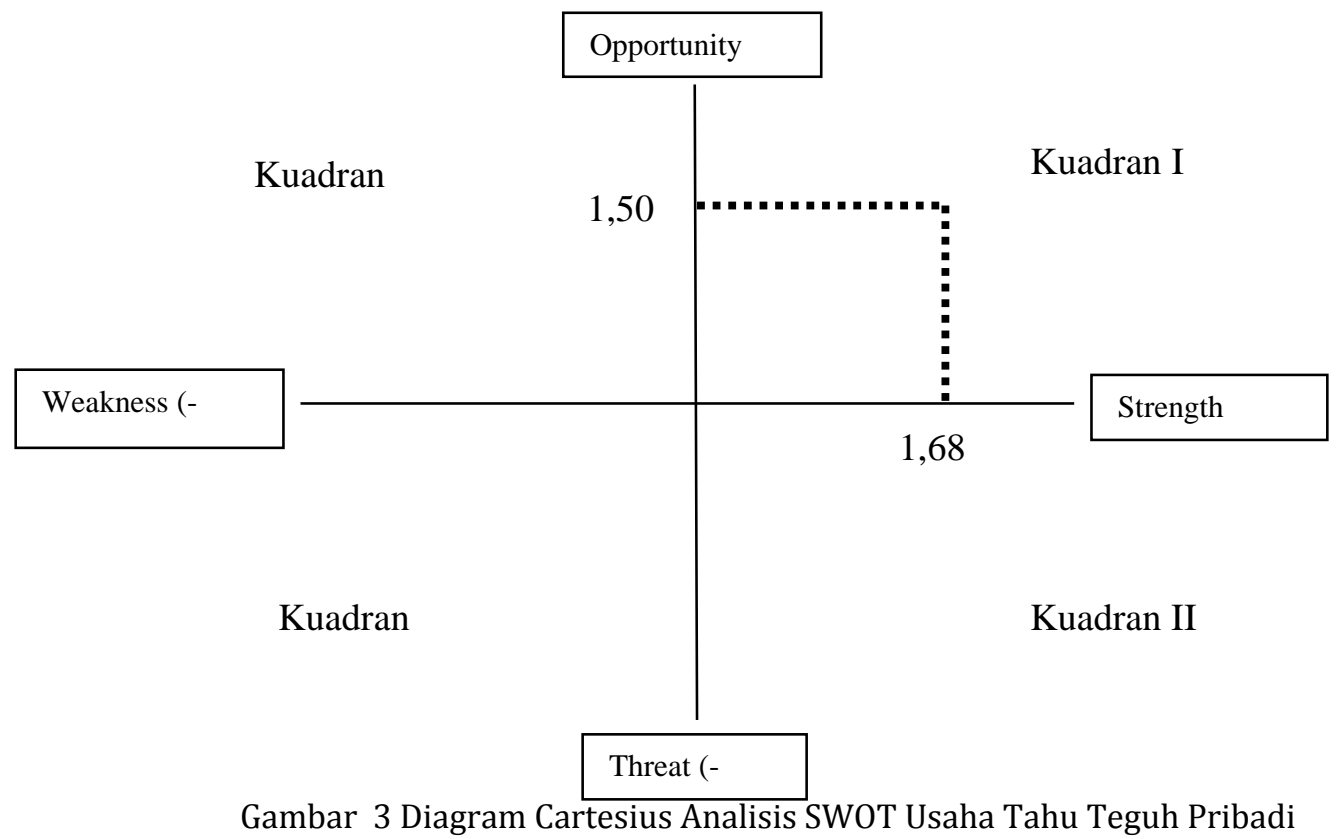

Dari gambar Cartesius diatas sangat jelas menunjukan bahwa Usaha Tahu Teguh Pribadi berada Pada Kuadran growt dimana kuadran tersebut merupakan situasi yang sangat menguntungkan perusahaan tersebut memiliki peluang dan kekuatan, sehingga dapat memanfaatkan peluang yang ada, strategi yang harus diterapkan dalam kondisi ini adalah mendukung kebijakan pertumbuhan yang agresif (Growth Oriented Strategy). Kebijakan pertumbuhan yang agresif dapat disimpulkan sebagai suatu pemikiran yang logis, konseptualisasi hal-hal prioritas (Dalam jangka panjang maupun pendek) untuk dijadikan acuan untuk menentukan langkah ataupun tindakan yang akan dilakukan. Strategi pertumbuhan yang agresif dapat dimulai dengan memberikan pelayanan yang baik kepada konsumen serta memenuhi kebutuhan pelanggan. Menghadapi kenyataan seperti ini, strategi yang semestinya dilakukan untuk pengembangan Usaha Tahu Teguh Pribadi sebagaimana ditunjukkan pada Tabel 8 berikut ini: 
Tabel 6. Matrik SWOT Pemasaran UKM Tahu Teguh Pribadi

\begin{tabular}{|c|c|c|}
\hline Opportunity Threat & $\begin{array}{l}\text { Strength (S) } \\
\text { 1. Pengalaman usaha di bidang industri } \\
\text { tahu } \\
\text { 2. Hubungan yang baik antar pengusaha } \\
\text { 3. Harga yang terjangkau } \\
\text { 4. Produk yang ditawarkan berkualitas } \\
\text { dan unggulan } \\
\text { 5. Saluran distribusi yang pendek } \\
\text { 6. Kontinuitas produksi terjamin }\end{array}$ & $\begin{array}{l}\text { Weakness }(\mathbf{W}) \\
\text { 1. Modal usaha terbatas } \\
\text { 2. Tingkat pendidikan yang masih } \\
\text { rendah } \\
\text { 3. Tidak adanya keragaman produk } \\
\text { 4. Promosi terbatas } \\
\text { 5. Belum melaksanakan pengawasan } \\
\text { dan evaluasi secara baik } \\
\text { 6. Limbah belum dikelola secara } \\
\text { optimal } \\
\text { 7. Pengelolaan kurang higienis }\end{array}$ \\
\hline \begin{tabular}{ll} 
& \multicolumn{1}{c}{ Opportunity (0) } \\
1. & $\begin{array}{l}\text { Adanya perhatian dari } \\
\text { Pemerintah }\end{array}$ \\
2. & $\begin{array}{l}\text { Adanya kepercayaan dari } \\
\text { konsumen }\end{array}$ \\
3. & $\begin{array}{l}\text { Kontinuitas bahan baku } \\
\text { terjamin }\end{array}$ \\
4. & $\begin{array}{l}\text { Pedagang membantu } \\
\text { memperluas pemasaran }\end{array}$ \\
5. & $\begin{array}{l}\text { Perkembangan teknologi } \\
\text { pengolahan }\end{array}$
\end{tabular} & $\begin{array}{l}\text { Strategi S-O } \\
\text { 1. Mempertahankan kualitas produk } \\
\text { dengan pemanfaatan perkembangan } \\
\text { teknologi untuk menjaga } \\
\text { kepercayaan konsumen }(\mathrm{S} 1, \mathrm{~S} 4 \text {, } \\
\text { O2,05) } \\
\text { 2. Membentuk asosiasi/serikat } \\
\text { pengusaha tahu guna menjaga } \\
\text { bargaining position terhadap } \\
\text { pemasok }(\mathrm{S} 2, \mathrm{~S} 5,03,04)\end{array}$ & $\begin{array}{l}\text { Strategi W-O } \\
\text { 1. Meningkatkan volume penjualan } \\
\text { melalui diversifikasi produk dengan } \\
\text { memanfaatkan kebijakan mengenai } \\
\text { kuliner. (W3,W4,01,02) } \\
\text { 2. Peningkatan kualitas } \backslash \text { SDM melalui } \\
\text { program program dari pemerintah. } \\
\text { (W2,01) }\end{array}$ \\
\hline 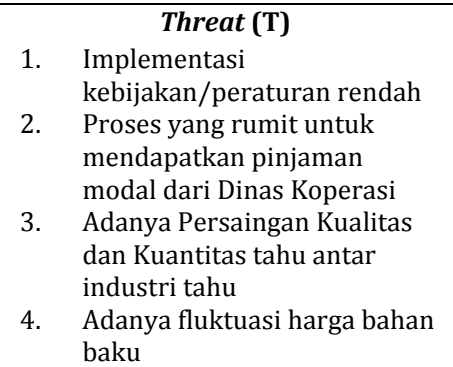 & 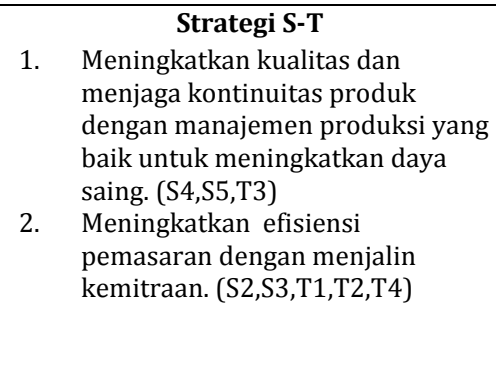 & $\begin{array}{l}\text { Strategi W-T } \\
\text { 1. Penggunaan SOP secara sederhana } \\
\text { guna keefektifan dan efissien. } \\
\text { (W1,W5,W6,W7,T1,T2,T4) } \\
\text { 2. Peningkatan jejaring permodalan } \\
\text { dan promosi melalui kemasan } \\
\text { produk serta peningkatan SDM } \\
\text { (W1,W2,W4,T2) }\end{array}$ \\
\hline
\end{tabular}

Sumber: data primer 2019

\section{Pembahasan}

\section{Strategi S-O (Strenght-Opportunity)}

Strategi ini merupakan gabungan dari faktor internal (Strenght) dan faktor eksternal (Opportunity), strategi ini dibuat berdasarkan pemikiran dengan memanfaatkan seluruh kekuatan untuk merebut dan memanfaatkan peluang sebesar-besarnya. Strategi SO yang di tempuh Usaha Tahu Teguh Pribadi yaitu:

1. Mempertahankan kualitas produk dengan pemanfaatan perkembangan teknologi untuk menjaga kepercayaan konsumen.

Pengusaha tahu dapat memanfaat kan perkembangan teknologi untuk dapat memproduksi tahu yang lebih enak,higiens, tahan lama sehingga konsumen tidak akan mudah untuk berpindah ke pengusaha yang lain nya

2. Membentuk asosiasi/serikat pengusaha tahu guna menjaga bargaining position terhadap pemasok. Pembentukan asosiasi dapat mempermudah pengusaha untuk membeli kacang kedelai dengan harga yang lebih murah. Asosiasi ini juga membantu pengusaha berperan sebagai pihak yang memiliki posisi tawar dipasar, sehingga pengusaha secara bersama-sama bisa menentukan harga jual ketika harga kedelai naik di pasaran.

\section{Strategi W-0}

Strategi W-O (Weakness-Opportunity) atau strategi kelemahan peluang adalah Strategi untuk meminimalkan kelemahan yang ada untuk memanfaatkan peluang eksternal. Alternatif strategi W-O yang dapat dirumuskan adalah :

1. Meningkatkan volume penjualan melalui diversifikasi produk dengan memanfaatkan kebijakan mengenai kuliner

Terdapat berbagai macam cara untuk dapat meningkatkan volume penjualan suatu produk yaitu salah satunya dengan diversifikasi produk. Diversifikasi produk yang di buat haruslah berdasarkan hasil survei yg telah terlebih dahulu di jalankan sehingga produk yang di produksi dapat sesuai dengan selesara konsumen dan nilai tambah tahu dan keuntungan akan meningkat. 
2. Peningkatan kualitas SDM melalui program-program dari pemerintah.

Masih rendahnya SDM pada industri kecil usaha Tahu Teguh Pribadi membuat rendahnya tingkat daya saing. Peningkatan SDM ini dapat dilakukan dengan bantuan pemerintah dengan cara pengadaan pelatihan para pelaku usaha serta melakukan studi banding agar pelaku usaha dapat menjadikan industri kecil nya siap bersaing dalam pasar global.

\section{Strategi S-T}

Strategi S-T (Strenght -Threat) atau strategi kelemahan ancaman adalah strategi defensif untuk meminimalkan kelemahan internal dan menghindari ancaman eksternal. Alternatif strategi yang dapat dirumuskan adalah :

1. Meningkatkan kualitas dan menjaga kontinuitas produk dengan manajemen produksi yang baik untuk meningkatkan daya saing.

Kualitas Produksi tahu merupakan salah satu faktor penting yang harus di perhatikan. Kualitas tahu yang baik sangat tergantung dari beberapa faktor, salah satunya dengan mmanajemen produksi yang baik pula. Agar tidak kalah dalam persaingan maka kualitas dan kontinuitas produk tahunya harus selalu dijaga sehingga mampu untuk meningkatkan laba.

2. Meningkatkan efisiensi pemasaran dengan menjalin kemitraan.

Terjalinnya kemitraan masyarakat dapat meningkatkan efisiensi pemasaran, selain itu menjalin kerjasama antar sesama pengusaha,pedagang dan koperasi. Hubungan kemitraan ini juga merupakan suatu strategi bisnis dengan prinsip saling membutuhkan dan saling membesarkan.

\section{Strategi W-T}

Strategi W-T (Weakness -Threat) atau strategi kekuatan-ancaman adalah strategi untuk mengoptimalkan kekuatan internal yang dimiliki dalam menghindari ancaman. Alternatif strategi $\mathrm{W}$ - $\mathrm{T}$ yang dapat dirumuskan adalah :

1. Penggunaan SOP secara sederhana guna keefektifan dan efissien

Penggunaan SOP (Standar Operasional Prosedur) pada usaha tahu dapat sangat membantu karena di dalam SOP tersebut dapat memperjelas alur tugas,tanggung jawab dan pedoman dalam melaksanakan pekerjaan rutin, memuat langkah operasional agar dapat menyelesaikan tugas dengan cepat, tepat waktu dan tepat biaya.SOP ini juga mengatur siapa yang harus mengerjakan,apa yang harus dilakukan dan kapan harus dilaksanakan. Sehingga semua pekerjaan dapat di laksanankan dengan teratur dan tercipta disiplin kerja antar karyawan. Pengusaha juga dapat melakukan evaluasi pada waktu-waktu tertentu dalam rangka improvement agar lebih efektif dan efisien.

2. Peningkatan jejaring permodalan dan promosi melalui kemasan produk serta peningkatan SDM Perluasan jaringan permodalan dapat membantu pengusaha untuk mendapat kucuran dana bantuan dari lembaga pembiayaan pemerintah ataupun non pemerintah semisalnya bank,koperasi dan lembaga pembiayaan lain nya. Dalam hal ini pemerintah sebagai fasilitator untuk memeperoleh modal dari lembaga pembiayaan. Dengan adanya modal, maka diharapkan pengusaha dapat dan mampu meningkatkan sumberdaya manusia yang terdapat didalam nya.

\section{KESIMPULAN}

1. Matriks IFAS (Internal Factor Analysis Summary) menunjukan bahwa faktor kekuatan dan kelemahan memiliki total skor 3,01, hal ini mengindentifikasi bahwa Usaha Tahu Teguh Pribadi berada pada posisi internal yang begitu kuat, dimana usaha ini memiliki kekuatan internal baik dari segi produk dan strategi.

2. Sedangkan pada Matrik EFAS (External Factor Analysis Strategi ) menunjukkan bahwa faktor peluang dan ancaman memiliki nilai total 3,16 hal ini mengidentifikasi bahwa Usaha Tahu Teguh Pribadi tersebut merespon peluang yang ada dengan cara yang luar biasa dan menghindari ancaman-ancaman di pasar industrinya. Perusahaan juga memiliki peluang untuk terus berinovasi sesuai dengan hasil yang telah ditetapkan dari berbagai analisis yang telah yang dilakukan pada bab sebelumnya.Usaha Tahu Teguh Pribadi telah terbukti bisa berkembang dengan penelaahan dengan menggunakan analisis SWOT.

3. Berdasarkan diagram Cartesius menunjukan bahwa Usaha Tahu Teguh Pribadi berada pada kuadran Growth dimana kuadran tersebut merupakan situasi yang sangat menguntungkan. Perusahaan tersebut memiliki peluang dan kekuatan sehingga dapat memanfaatkan kecanggihan teknologi untuk meningkatkan kegiatan promosi agar menambah jumlah pelanggan, dan lebih meningkatkan produksi yang lebih efektif untuk memenuhi kebutuhan pelanggan, serta mempertahankan kualitas kualitas Tahu Teguh Pribadi. 
4. Strategi SO (Strenght-Opportunity) maka diperoleh lah faktor yang harus dipertahankan untuk mampu mengambil peluang yang ada yaitu : Peningkatan kualitas produk dengan pemanfaatan perkembangan teknologi untuk menjaga kepercayaan konsumen daan membentuk asosiasi/serikat pengusaha tahu guna menjaga bargaining position terhadap pemasok.

5. Strategi W-O (Weakness-Opportunity) diperoleh hasil yaitu: Meningkatkan volume penjualan melalui diversifikasi produk dengan memanfaatkan kebijakan mengenai kuliner dan Peningkatan kualitas SDM melalui program-program dari pemerintah.

6. Strategi S-T (Strenght -Threat) menampakkan hasil yaitu: Meningkatkan kualitas dan menjaga kontinuitas produk dengan manajemen produksi yang baik untuk meningkatkan daya saing. Serta dapat meningkatkan efisiensi pemasaran dengan menjalin hubungan kemitraan

7. Strategi W-T (Weakness- Threat) yaitu": Penggunaan SOP secara sederhana guna keefektifan dan efissien. Serta Peningkatan jejaring permodalan dan promosi melalui kemasan produk serta peningkatan SDM

\section{SARAN}

Adapun saran yang dapat penulis berikan dalam penetapan strategi Usaha Tahu Teguh Pribadi adalah sebagi berikut:

1. Usaha Tahu Teguh Pribadi hendaknya membuat diversifikasi produk sehingga dapat meningkatkan nilai tambah pada tahu. Namun dengan adanya diversifikasi ini memberikan konsekuensi terhadap penambahan modal usaha. Pemanfaatan teknologi dapat membantu pengusaha mempertahankan kualitas produk serta dapat dengan cepat memenuhi kebutuhan konsumen.

2. Usaha Tahu Teguh Pribadi di harapkan dapat meningkatkan kemasan produk, menjaga ke higienisan produk serta tempat produksi,pengolahan limbah hasil tahu sehingga dapat dimanfaatkan lebih lanjut bekerja sama dengan berbagai macam pihak sehingga dapat meningkatkan jejaring pemasaran.

3. Pemerintah memgadakan event (pameran,pesta kuliner) dengan mengikut sertakan para pengusaha tahu. Serta memberikan pembinaan dan dapat meningkatkan akses dalam hal peminjaman modal usaha, dengan perbankan dan lembaga lainnya.

\section{Daftar Pustaka}

Arikunto, S.. 2007. Prosedur Penelitian Suatu Pendekatan Praktek Edisi Revisi VI. Rineka Apta, Jakarta.

Cannon, Perreault dan McCarthy. 2009. Pemasaran Dasar Pendekatan Manajerial Global Buku 2 Edisi 16. Jakarta: Salemba Empat.

Esterberg, Kristin G., 2002. Qualitative Methods in Social Research, Mc. Graw Hill, New York.

Hamidi. 2010. Metode Penelitian Kualitatif. Malang: UMM Press.

Miles,M.B, Huberman,A.M, dan Saldana,J. 2014. Qualitative Data Analysis, A Methods Sourcebook, Edition 3. USA: Sage Publications. Terjemahan Tjetjep Rohindi Rohidi, UI-Press.

Michael, R. Duane, dkk.2001. Manajemen Strategi.Salemba Empat: Jakarta.

Manullang. 2013. Pengantar Bisnis. Jakarta. Indeks.

McCarthy, E.J dan W.D Perreault.1995. Intisari Pemasaran: Sebuah ancaman global .Jakarta: Jilid Satu Edisi Keenam Binarupa Aksara.

Pearce II, Jhon A. dan Robinson Richard B.Jr.2008. Manajemen Strategis 10.Salemba Empat :Jakarta.

Rangkuti, Freddy. 2009. Strategi Promosi yang Kreatif dan AnalisisKasus Integrated Marketing Communication. Jakarta : PT. GramediaPustakaUtama.

Sugiyono. 2012. Metode Penelitian Pendidikan: Pendekatan Kuantitatif, Kualitatif, dan R\&D. Bandung: Alfabeta.

Solihin, Ismail.2012. Manajemen Strategik.Universitas Widyatama: Bandung 